\title{
Achieving Sustainable Development Goals from a Water Perspective
}

\section{OPEN ACCESS}

Edited by:

David Tickner,

WWF-UK, UK

Reviewed by:

Nathanial Matthews,

Consultative Group on International Agricultural Research, Sri Lanka

Mark Zeitoun,

University of East Anglia, UK

*Correspondence:

Anik Bhadur

a.bhaduri@griffith.edu.au

${ }^{\dagger}$ Present Address:

Afreen Siddiqi,

Belfer Center for Science and International Affairs, John F. Kennedy

School of Government, Harvard

University, Cambridge, MA, USA;

Vanesa R. Osuna,

CUNY Advanced Science Research

Center, Environmental Crossroads

Initiative, New York, NY, USA

Specialty section:

This article was submitted to

Freshwater Science,

a section of the journal

Frontiers in Environmental Science

Received: 20 April 2016

Accepted: 22 September 2016

Published: 14 October 2016

Citation:

Bhaduri A, Bogardi J, Siddiqi A, Voigt $H$, Vörösmarty $C$, Pahl-Wostl $C$, Bunn SE, Shrivastava P, Lawford R,

Foster S, Kremer H, Renaud FG,

Bruns A and Osuna VR (2016)

Achieving Sustainable Development

Goals from a Water Perspective.

Front. Environ. Sci. 4:64.

doi: 10.3389/fenvs.2016.00064

\begin{abstract}
Anik Bhaduri ${ }^{1,2 *}$, Janos Bogardi ${ }^{3}$, Afreen Siddiqii ${ }^{4 \dagger}$, Holm Voigt ${ }^{3}$, Charles Vörösmarty ${ }^{5}$, Claudia Pahl-Wostl ${ }^{6}$, Stuart E. Bunn ${ }^{1}$, Paul Shrivastava ${ }^{7}$, Richard Lawford ${ }^{2}$, Stephen Foster ${ }^{8}$, Hartwig Kremer ${ }^{9}$, Fabrice G. Renaud ${ }^{10}$, Antje Bruns ${ }^{11}$ and Vanesa R. Osuna ${ }^{3+}$
\end{abstract}

${ }^{1}$ Australian Rivers Institute, Griffith University, Brisbane, QLD, Australia, ${ }^{2}$ Sustainable Water Future Programme, Brisbane, QLD, Australia, ${ }^{3}$ Center for Development Research (ZEF), University of Bonn, Bonn, Germany, ${ }^{4}$ Engineering Systems Division, Massachusetts Institute of Technology, Cambridge, MA, USA, ${ }^{5}$ Department of Civil Engineering, The City College of New York, New York, NY, USA, ${ }^{6}$ Institute for Environmental Systems Research, University of Osnabrück, Osnabrück, Germany, ${ }^{7}$ Future Earth, Montreal, QC, Canada, ${ }^{8}$ Global Water Partnership, London, UK, ${ }^{9}$ Science Division, UN Environment, Copenhagen, Denmark, ${ }^{10}$ Institute for Environment and Human Security, United Nations University, Bonn, Germany, ${ }^{11}$ Governance and Sustainability Lab, University of Trier, Trier, Germany

Efforts to meet human water needs at local scales may cause negative environmental externalities and stress on the water system at regional and global scales. Hence, assessing Sustainable Development Goals (SDGs) targets requires a broad and in-depth knowledge of the global to local dynamics of water availability and use. Furthermore, interactions and trade-offs between different SDG targets may lead to sub-optimal or even adverse outcomes if the set of actions are not properly pre-designed to consider such inter-linkages. Thus, scientific research and evidence have an important role to play in facilitating the implementation of SDGs through assessments and policy engagement from global to local scales. This paper addresses some of these challenges related to implementation and monitoring of the targets of the SDGs from a water perspective, based on the key findings of a conference organized in 2015 focused on three essential aspects of SDGs: indicators, inter-linkages, and implementation. The paper argues that indicators should not be too simple and should ultimately deliver sustainability measures. The paper highlights that remote sensing and earth observation technologies can play a key role in supporting the monitoring of water targets. It also recognizes that implementing SDGs is a societal process of development, and there is a need to link how SDGs relate to public benefits and to communicate this to the broader public.

Keywords: SDG6, global water, nexus, environment, indicators

\section{INTRODUCTION}

Human activities play a dominant role compared to many other natural processes in changing the biosphere and affecting the functioning of the Earth system (Vörösmarty et al., 2010, 2015a,b; Green et al., 2015). Stresses on the earth system and exhaustion of its resources are causing interrelated, complex, and frequently unwanted outcomes that include impacts on the water system and unprecedented changes to global water circulation (Vörösmarty et al., 2004, 2015a). Actions at the local scale to meet human water needs may trigger increased environmental stress at regional and global scales, and thus create a trade-off between human water needs and environmental sustainability. As stated in the first sentence of the World Water Development Report 2015, "water is at the core of sustainable development" (UNESCO-WWAP, 2015); and the latter is 
strongly connected to the availability and access to sufficient quantity and quality of water for the preservation of healthy ecosystems and is critical for socio-economic and human development. Yet increased pressure on the water system is observed through increased global demand and mismanagement of our water resources and water-related infrastructure. The following illustrate some of the serious threats to water-related sustainable development:

- Approximately 1.4 billion people live in river basins where water use exceeds recharge rates (UNDP, 2006).

- In developing countries, almost $90 \%$ of sewage is discharged without any treatment (UNESCO-WWAP, 2012).

- Increased use of fertilizer for food production, combined with increased wastewater effluent results in $10-20 \%$ increase in nitrogen flow in global rivers (UNEP, 2007).

- Globally, some 750 million people (mostly in rural areas) lack access to an improved source of drinking water

- 170 million people rely on untreated surface water (Clarke et al., 2002)

- 1.8 billion people have used a source of drinking water with fecal contamination (UNICEF WHO, 2015).

Thus, while the manifestations of human water access at the expense of freshwater ecosystem health may be at both local and regional scales, the widespread occurrence of both makes them a global issue (Haddeland et al., 2014, Wheater and Gober, 2015). The governance systems in both industrialized and developing countries lack the capacity to handle these challenges and uncertainties (Pahl-Wostl et al., 2013; Pahl-Wostl, 2015). Superimposing the different elements of global change, the question thus arises of how sustainable human development can be ensured while safeguarding earth's vital life-support system on which the welfare of current and future generation depends?

In September 2015, the UN General Assembly responded by adopting a set of seventeen Sustainable Development Goals (SDGs). It emphasized the importance of water as an integral part of human development, and ecosystem needs (Harlin and Kjellén, 2015; UN-Water, 2015). However, assessing whether the SDG targets related to water are "SMART", i.e., Specific, Measurable, Attainable, Realistic, and Timely, requires a broad and in-depth knowledge of the global to local dynamics of water availability and its use (BWS, 2013). Furthermore, interactions and trade-offs between different SDG targets may lead to suboptimal or even adverse outcomes if the set of actions are not properly pre-designed considering such inter-linkages (ICSU, 2016). Scientific research and evidence can play a strong role in facilitating the implementation of SDGs through assessments and policy engagement from global to local scales (Lu et al., 2015; Bunn, 2016). This paper addresses the challenges related to integrated implementation and monitoring of the targets of the SDGs from a water perspective ${ }^{1}$.

It is a paramount task to select "actionable" indicators measuring progress toward the achievement of the adopted 169

\footnotetext{
${ }^{1}$ The paper, however, do not cover topics like conflict resolution, south-south cooperation, and efficiency of development assistance in the context of SDG as significant details of such issues are beyond the scope of this paper.
}

targets of the 17 SDGs on local, national and global scales, particularly when data in many parts of the world are either non-existent or not readily accessible. Thus, indicator-based assessments will have to rely on intensified monitoring and sustained follow-up. Beyond measuring success (or the lack of it) on 169 accounts, the indicators have to capture the strong interlinkages and interdependencies among various goals and targets (Griggs et al., 2013; Nilsson et al., 2016). This may imply the use of some common indicators that could measure simultaneous progress toward different targets. The implementation of the SDGs also requires societal progress, development, and deployment of capacities, and changes in human behavior. Ultimately, these changes should also be monitored to ensure successful and sustainable implementation of the SDGs. The SDG framework poses some conceptual as well as implementation challenges that require enhancing collaboration between the policy and scientific communities and other stakeholders in industry and agriculture from the outset.

Recognizing that the science community had no prior formal involvement, the Global Water System Project (now called Sustainable Water Future Programme) sponsored by the German Ministry of Education and Research (BMBF) organized a conference on "Sustainable Development Goals: A Water Perspective" in August 2015 in Bonn, Germany. The conference was attended by more than 200 experts from various fields of the water sector and played a unique and timely role in enabling the science community to interact with the international policy consultation process to inform and catalyse action by key actors: policymakers, intergovernmental and non-governmental organizations, the private sector and educators as agents of change. Panel and roundtable discussion sessions enabled vivid exchange and discussion on topics specific to SDG 6 (ensuring availability and sustainable management of water and sanitation for all) as well as related goals and targets.

The focus of the conference was on "three I"'s: indicators, interlinkages and implementation of the SDGs. The theme related to indicators framed discussions on how to develop appropriate indicators and indices across several disciplines for water, wastewater and water-related disasters and address data integration and monitoring frameworks. Panel sessions on inter-linkages highlighted trade-offs and complementarities between different SDGs. While the conference adopted a "water perspective" the focus was not only on the six "what to achieve" and two "how to do" targets of the dedicated water goal (SDG-6), but also on the potential interlinkages with other goals and targets, including, among others SDG2 (food security), SDG-3 (health and wellbeing), SDG-11 (resilient cities), SDG-12 (sustainable consumption), and SDG15 (freshwater ecosystems). The implementation theme focussed on the practice, science, and policy links and explored how sharing available information, knowledge, and action gaps, as well as using viable instruments and approaches can contribute to implementation of SDGs. Each session identified several research and action gaps with respective recommendations that have been summarized and discussed during the synthesis session which are the basis for the recommendations provided in this paper. 
Table 1 summarizes the challenges related to implementation and monitoring of the targets of SDG-6 and lists some critical comments, key recommendations formulated by the science community, and other stakeholders during the conference. The targets are classified into "how to do" and "what to achieve" targets. The recommendations and research gaps in the table have been updated given more recent developments related to the definition and adoption of the official indicators which will be used for monitoring and reporting purposes (UN-Water, 2016).

\section{MEANINGFUL INDICATORS FOR MULTI-LEVEL ASSESSMENT}

Meaningful indicators are most needed to assess sustainable water use for humans and natural systems considering both quantitative and qualitative aspects (Hák et al., 2016). Current indicators developed to track water-related SDGs, however, lack clear-cut definitions including minimum standards and guidance and suffer ambiguity (e.g., what is "improved sanitation" or "appropriate transboundary cooperation") and may fail to provide a clear understanding of the progress that will be made on SDGs. For example, definitional uncertainties and misinterpretation can even discredit target achievements claims. The shift of semantics to "improved" water supply in Millennium Development Goal MDG 7 drinking water target created sizable uncertainty in whether the target of providing "safe drinking water" was achieved at all (Onda et al., 2012).

In principle, indicators should be SMART (Specific, Measurable, Attainable, Realistic, and Timely), easy to apply and should inform policy makers on progress made toward sustainability. Indicators are not intended to give implementation prescriptions for countries, since every country should translate these targets and create roadmaps for achieving them based on their own realities (ICSU, ISSC, 2015). On the other hand, indicators should not be too simple and ultimately deliver sustainability measures so that we will be able to understand the trajectories that ensure resource efficiency, sustainability and well-being simultaneously. It is also noted that even if indicators are "SMART," they may not accurately reflect the over-arching goals. The tensions between indicators related to availability of "safe water" vs. equity and affordability create challenges in aggregating competing measures to assess progress toward the overall goal of water and sanitation for all. A drinking water service could be "safely managed" but the indicator measuring the proportion of population using safely managed drinking water services does not reflect on the affordability and equitable distribution of water. Urban poor, for instance, pay many times more for a liter of water than their richer neighbors, as they often have to buy their water from private vendors (UN-Water, 2011). As suggested in Table 1, an indicator measuring the affordability of drinking water supply can address this and deal with such discrepancy. Similarly, in addressing the targets toward substantially increasing water-use efficiency across all sectors, the indicators do not address the affordability of farmers, households in using efficient methods to save water; and also indicators do not measure how the "saved" water can be used equitably, sustainably, and efficiently which is key to understanding the benefits of water use efficiency. Many discriminatory national level policies shaped by political economy lead to such inequitable distribution of services and resource. Sustainable Development Goal 16 in achieving peace, justice, and strong institutions address this in a broader context and how human rights and effective governance based on the rule of law could be an important way for sustainable development.

While many of the indicators, as described in Table 1, will be measured at national level, there is also a risk of overlooking and neglecting global dynamics with large and possibly irreversible impacts on humans and nature if the focus of the indicators is only on local processes. Also, there is a particular concern that an approach which assesses water state only on a global scale may mask critically important and unique local contexts that influence water risk. Given the reciprocal benefits of considering local to global scales, a continuum approach from local to global and assess systemic risk at different levels and for different sectors is needed so that it can inform policy makers on progress made, and provide a reality-based global vision on sustainability. At the global level, appropriate risk metrics are needed to assess whether humans are in a safe and sustainable operating space of the global water system and still can meet their essential needs (Rockström, 2009). At a regional and local level, water risk assessment is needed to guide social, private, and public decisions on investment under risk and uncertainty, and also in developing appropriate institutions and coordinating implementation and enforcement plans.

The number of variables for quantifying such indicators and indicator sets need to be sufficient to capture complexity, but it should also be small enough to be manageable for monitoring. Scenarios are useful tools to visualize possible water futures and can be used to see if potential indicators can characterize the outcomes of complex scenarios. For scenario development, time series data are needed which are spatially scalable, consistent, and harmonized. Such information backed by scientific evidence can allow for distinguishing between "what can be done," "what can't be done," and "what are the costs of inaction" to implement water-related goals including social implications.

There is a need for the development of scientifically sound assessment and regulatory guidelines that can help to address the gaps in understanding the interaction between stressors and their impacts on the ecosystem health of freshwater bodies. Details of such knowledge gaps and recommendations are laid out in Table 1.

Water quality is strongly linked to SDGs, focusing on the sustainability of water use for future generations. Declining water quality, for instance with harmful implications in the long run for socio-ecological systems as a whole, has become a global issue of concern. Today, we recognize that water scarcity is gradually becoming even more a quality than a quantity problem. Target 6.3 calls to improve water quality by reducing pollution, eliminating dumping, and minimizing release of hazardous chemicals and materials, halving the proportion of untreated wastewater and substantially increasing recycling and safe reuse 


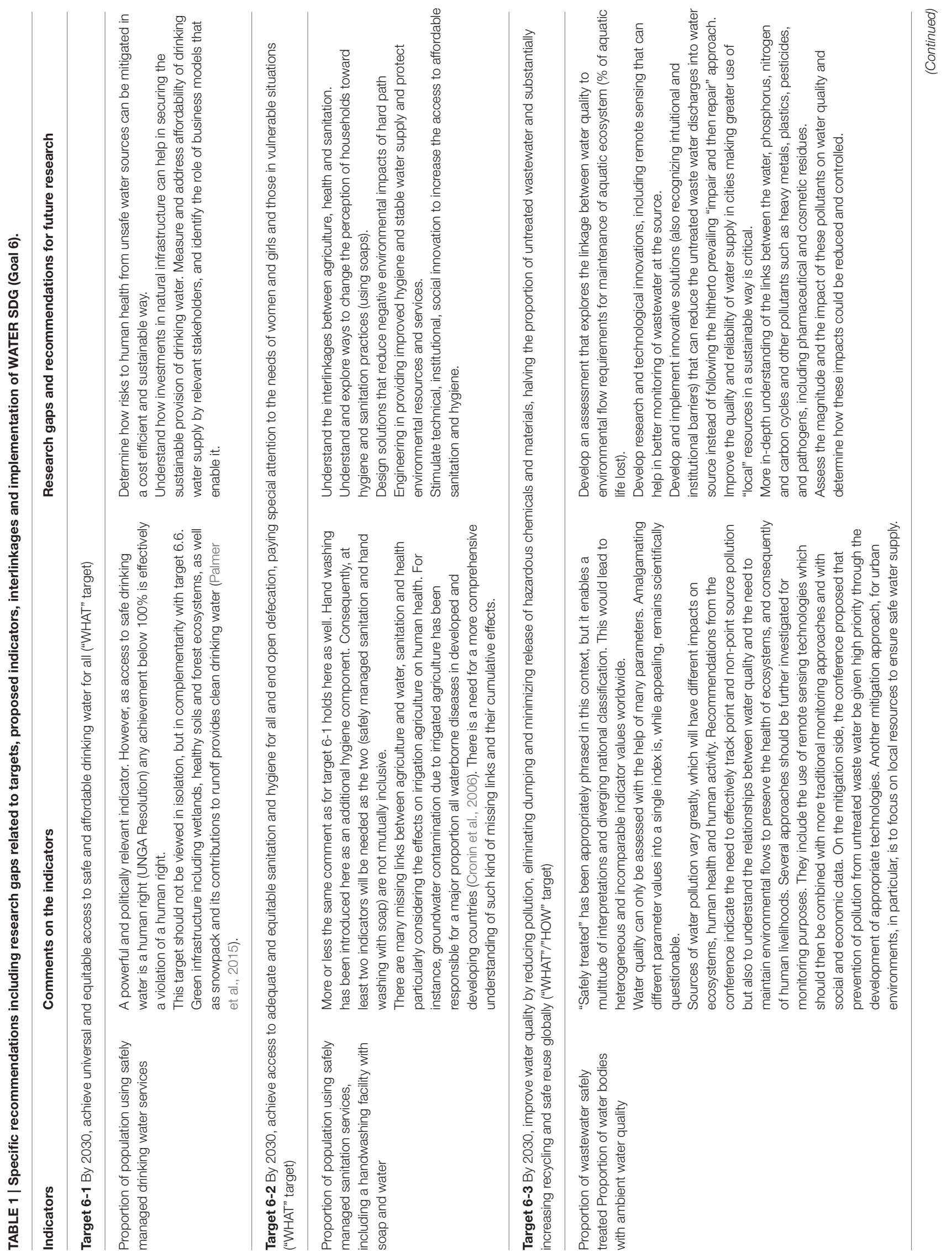




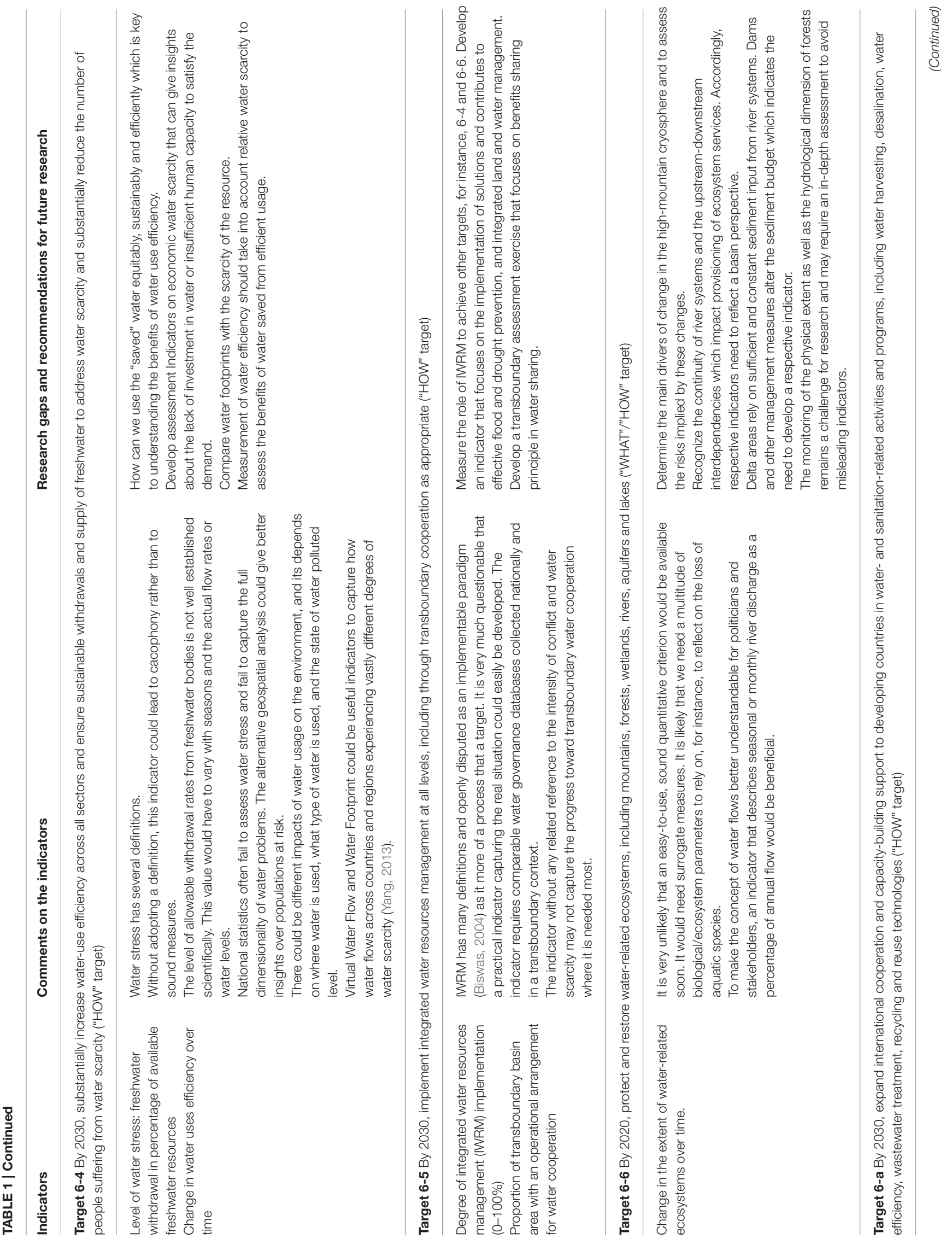


globally. There exists a wide range of possible water quality indicators, and yet there remains a formidable challenge to assess the quality status of freshwater bodies adequately in many parts of the world. The indicators, as described in Table 1, do not reflect how different sources of water pollution have different impacts on ecosystems, human health, and human activity. Some of the anthropogenic factors of water quality degradation are agricultural runoff containing organic pollutants, chemical and medicine residues, and also global climate change which increases the water temperature and change the characteristics of freshwater systems (e.g., though alteration of dilution capacity); air pollution deposition into aquatic systems from local and distant sources (Alcamo, 2011).

In order to understand the relationships between water quality and human well-being and environment, there is a need for an effective tracking of point and non-point source pollution. Science can play a role in providing an in-depth understanding of the links between water, phosphorus, nitrogen and carbon cycles and other pollutants, assessing the magnitude and the impact of these pollutants on water quality and in determining how these impacts could be reduced and controlled (Refer to Table 1). Such assessments at different scales can help to identify the root causes of the problem and help to fill up the knowledge gap to formulate the right policies in implementing SDGS.

Many global measures or indicators do not reflect the household or community level action toward or away from sustainability. The sustainability conditions that may appear at the macro level may not hold at the household (micro) level. There is a strong need also to include household and community level water quality and sanitation assessments to account for the multiple scale nature of the respective target achievement. For instance, in order to gain more information on wastewater treatment which is a crucial part of sanitation, the Yale Environmental Performance Index (EPI) has been developed as a national wastewater treatment indicator (Malik et al., 2015). An interactive map of the percentage of wastewater treated per country performance can be established using crowdsource data to overcome data scarcity in this field (Hsu et al., 2014).

Even more "on the ground" approaches have been taken up for example by the Swachh Bharat Mission (SBM) in India. Their sanitation campaign aims at promoting the use and construction of latrines in rural areas. The previous monitoring system was based on expenditure for sanitation, thus not directly observing de facto toilet construction leading to significant over-reporting: $80 \%$ of the toilets being recorded could not be verified as existing by the Census 2011. In order to improve the monitoring system, the SBM is setting up a smartphone based observation system. Using geo-tagged pictures of latrines is a simple and efficient method to report household specific toilet construction and existence. Both cases could be used as baseline examples for SDG monitoring. However, neither of the procedures bridges the gap between local and global scale monitoring. Further, the issue still remains about the role of an indicator. An ideal SDG indicator may reflect on the sustainability of (i.e., lasting and delivering intended benefit) water management measures and not the one that 
requires counting of installed latrines per capita or other simply quantifiable achievements.

\section{ROLE OF EARTH OBSERVATION}

As mentioned in Table 1, national statistics often fail to assess water stress and fail to capture the full dimensionality of water problems. The alternative geospatial analysis could give better insights on populations, and environment at risk. Remote sensing and earth observation technologies can play a key role in supporting the monitoring of water targets, particularly where temporal data are unavailable, for instance on freshwater biodiversity. It can also identify emerging risks of underachievement, and help to understand responses when economic changes take place. These technologies could lead to a cost-effective, high-quality, monitoring program for water, by providing global data to complement in situ data at national level (Lawford et al., 2013).

In situ measurements provide time series trends of the water system and its variability at specific locations. Earth Observation data are geospatially consistent and can provide estimates of distribution of water cycle variables at the spatial and time dimensional scale using interpolation of in situ data. For instance, data sets on precipitation have been improved largely by integrating higher frequency in situ point measurements with less frequent but spatially consistent satellite data to give better rainfall accumulation estimates (Hsu et al., 2012). In recent decades, satellites have been able to provide increasingly reliable information on other variables, soil moisture, river discharge, monitoring of water quality by measuring sediment loading, chlorophyll concentrations, algal blooms, and general turbidity, assessment of groundwater changes.

However, the importance of concomitantly strengthening local in situ field observations also has to be stressed, since these are usually required to diagnose cause-and-effect in the changes being observed. By combining earth observations with hydrologic and biophysical models as well as with socioeconomic data, water indicators can be monitored at high data resolutions and allow effective computation of complex water indices ICSU, (ICSU, ISSC, 2015).

\section{UNDERSTANDING THE SDG INTERLINKAGES}

While the SDGs are formulated as individual goals, they are hardly independent. Water runs as a common link through several of them, and the targets and indicators relating to freshwater systems are to be found not only in the dedicated water goal (goal 6) but also in other goals and indicators.

Groundwater systems serve as a useful example to illustrate some of the interconnections. Local, regional and continental aquifers are strategically significant, constituting the planet's major storage reserve of freshwater and representing a critical buffer for socioeconomic adaptation to climate and environmental change. Threats to their sustainability, associated with both excessive exploitation and quality degradation over the past 30-50 years (Foster et al., 2013), represent a potential impediment to achieving the SDGs-and this applies not only to the SDG-6 for water but also to SDG-2 on food security, SDG-3 on human health, SDG-11 on resilient cities and SDG-15 on protecting ecosystems and conserving biodiversity. In many ways, the proposed SDGs tend to "skate around" the critical consideration of absolute physical constraints on natural resources such as groundwater, and how these have been significantly reduced as a result of historically inadequate custodianship. The SDGs relating to food production, resilient cities, and aquatic ecosystems can only be achieved in the long term if underlying groundwater systems are conserved in "good status" and not subject to continued depletion and quality degradation.

The inter-linkages across the SDGs are many, and a full and systematic understanding of the links can offer an opportunity to formulate strategically policy interventions and solutions that simultaneously advance multiple goals (Waage et al., 2015). Furthermore, failure to achieve water-related goals propagates the risk of failure in achieving other interlinked goals. For instance, if we fulfill the clean water and sanitation (SDG-6) completely, it will significantly advance SDG-14 and 15 on preserving land and aquatic ecosystems respectively - and failure in achieving SDG-6 will negatively impact these connected SDGs. Thus, prioritizing the water targets could be one of the most important ways to maximize the potential stimulus of other SDGs.

The SDG indicators that are related to interconnected issues should be cautiously used and carefully interpreted. For instance, water quality is influenced by many factors (e.g., land degradation, human health, sanitation, etc.). However, the dedicated food security and human health goals (SDGs 2 and 3 respectively) have no water-related indicators that address this interlinkage.

The interconnections-or the nexi-between water, food, energy, land, and climate are been increasingly studied by researchers across multiple disciplines who recognize that understanding the important links is a necessary element for future sustainable development (Hoff, 2011; Rasul, 2014; Ringler et al., 2016) and as a response to global environmental change (Leck et al., 2015). The interconnections of water with agriculture (and food security and rural livelihoods), energy (particularly through hydropower but also with other energy systems), land (and ecosystems), public health (based on water quality and access), and sustainable cities and communities have long been highlighted. There has also been significant research on integrated water resources management (IWRM) that sought holistically to improve development and management of water sources (Grigg, 2008). But there is now emerging research that seeks to explicitly understand and account for the interconnections of water with other important sectors (such as that of agriculture, energy, urban, and rural development etc.) to inform policy design (Conway et al., 2015), technology selection (Siddiqi and Anadon, 2011), and institutional arrangements (Siddiqi et al., 2013; Scott et al., 2015). This research can serve as an important base to build toward further work in the context of the new SDGs 
for identifying and understanding their linkages for synergistic actions.

\section{SUPPORTING THE SDG IMPLEMENTATION PROCESS}

The implementation of the ambitious SDGs poses considerable challenges to water governance. Many water related problems arise from inadequate and dysfunctional governance, irrespectively whether physical scarcity is prevalent or not. A lack of institutional capacity is the central factor to explain the poor performance of water governance in many countries (Schuster-Wallace et al., 2015). The SDG implementation process must thus support the building of institutional capacity to achieve its goals. Water governance should be participatory, accountable, transparent, responsive, consensus orientated, effective and efficient, equitable and inclusive, and should respect the rule of law. This is also connected to Goal 16 which says "promote peaceful and inclusive societies for sustainable development" and target 16.3- "Promote the rule of law at the national and international levels, and ensure equal access to justice for all." It can also be considered as a call for a better transboundary and global level water governance; and it implies that access to justice, law are crucial elements in water governance (Orme et al., 2015).

It also raises the question: How can political will, institutional capacity and good governance be fostered so that SDG process could become a global process driving transformative change toward sustainability? It requires engaging policy, business, science and civil society at large, and formulating incentives that foster harmonized interlinked regulations and policies. It is key to recognize that implementing SDGs is a societal process of development. We need to link how SDGs relate to public benefits and communicate this to the broader public. For instance, the question can be framed as "how do we make water drinkable," rather than an abstract question of water quality without considering the direct or indirect human dimension.

\section{ACCELERATING INNOVATIONS FOR SUSTAINABLE DEVELOPMENT}

Many water initiatives and solutions exist, all around the globe that addresses these challenges, but frequently from a single, constrained perspective and often limited in geographic scale. Scientists are concerned with understanding the nature and impact of global change; businesses implement new strategies and products. Policy makers on all different levels attempt to mitigate and adapt to environmental impacts. Nongovernmental organizations raise awareness and actively protect and support impacted humans and nature. Despite these varied efforts, it is beyond any doubt that sustainable development requires accelerated technological, social, and institutional innovation.

The increasing demand for drastic reductions of environmental burdens and footprints of human consumption (e.g., water pollution and excessive withdrawals), implies that adaptation within existing technologies is not sufficient. Instead, a change in approach and a framework is needed that strongly connects problem identifiers with solutions implementers, knowledge generators and knowledge implementers while focusing on integrated solutions. Such a solution-oriented integrated approach can act as an antidote to the otherwise sluggish flow of evidence-based knowledge from water science to policy formulation and application. It can help to develop the trajectory from concrete actions and find solutions through the co-production and critical review of knowledge. This may be done by facilitating meaningful and sustained dialogues between different stakeholders (science, industry, policy makers, and civil society), which will help to stimulate the diffusion of innovation by identifying "demand pulls" instead of creating a "supply push." There is a need to bring forward best practices of technological, institutional, and social innovation that will help in policy design and ensure the twin goals of environmental conservation and economic development are not conflicting.

Obviously, there are still serious unresolved scientific, professional, and also societal challenges involved (Pahl-Wostl et al., 2013). It is not perceivable that conclusive answers will be found before the implementation of SDGs starts and inherent monitoring and indicator related decisions have to be made. This implies that the scientific community must remain involved and assist the implementation process which will last at least the coming 15 years. No doubt in many aspects it will have to be an adaptive "learning by doing and improving" process.

\section{ROLE OF WATER STORAGE INFRASTRUCTURE}

Infrastructure is mediating the flow of water resources between nature and society and within society. Hence infrastructure plays an important role in reducing existing inequalities (Bruns and Frick, 2014). Among large-scale water infrastructure, water storage plays a key role to mitigate the effects of scarce and unreliable occurrence of the natural resource and its frequent inability to match even legitimate water demands. Yet, no other large-scale engineering intervention is as controversial as dams and reservoirs. Thus, the potentially controversial debates over technical solutions can be well illustrated in the case of dams. These debates are not without any ideological motivation (Muller, 2012). There are indeed serious consequences for freshwater bodies, terrestrial ecosystems, and human society. Not only the displacement of people due to the impoundment of water but the differences between the (new infrastructure, and mainly downstream) beneficiaries and the affected (local) population pose serious challenges within a country, and even more in a transboundary context.

Despite the controversies around this topic, some argue that climate-change adaptation and the SDGs can only be achieved through the development of substantial additional water storage infrastructure (Bates et al., 2008; Muller et al., 2015). There is historical evidence that human water security ${ }^{2}$, and other

${ }^{2}$ There is a huge diversity in the definition of water security. In policy contexts, a water security definition can range from minimal access issues for meeting basic 
dimensions of human well-being, are positively correlated with the availability and size of water storage capacity per capita (Vörösmarty et al., 2010). A massive dam development process, propelled predominantly by funding from private sources, is already underway to respond to increasing energy needs (Zarfl et al., 2015). Potential co-benefits for agriculture are unlikely to be considered. Major existing reservoirs like the Kariba and Cahora Bassa dams on the Zambezi River are single purpose ones meant for hydropower generation. There is much to be learned on how to establish consensus in building dams to meet human water needs and save the river system from being turned into an engineered one. Meanwhile, the IPCC report (Jiménez Cisneros et al., 2014) indicates that along the course of climate change weather and streamflow phenomena will result in increased extremes on both ends of the spectrum. Thus, longer droughts and larger floods would imply again more storage volume to cope with it. However, building reservoirs as means of adaptation may trigger additional adaptation stress affecting both people and ecosystems associated with new dams and reservoirs. Reservoirs which are well designed and operated as multipurpose facilities can contribute to the achievement of several SDGs, including ecosystem-oriented ones. Improved energy, food and water security, but also disaster risk mitigation and securing environmental flows downstream can be attributed to dams and reservoirs, however, as already mentioned, it often comes at the price of deterioration of the natural features of freshwater ecosystems (Krchnak et al., 2011; Muller et al., 2015).

Groundwater reserves constitute the other major form of freshwater storage and also have specific (but very different) "infrastructure requirements" if they are to be used sustainably. There is a pressing need for an adequate monitoring network to keep under long-term review whether they are excessively depleted or progressively salinized by current regimes of withdrawal for irrigated agriculture and urban water supply. In most cases, their sustainable utilization to improve watersupply security and ensure ecosystem conservation will require conjunctive management with surface water resources (Foster and van Steenbergen, 2011) to take advantage of complementary hydrologic characteristics. This in turn often initially requires larger up-front capital investment and always needs strengthening of the "resource governance regime."

\section{FINANCING THE WATER SDG}

The ambitious 2030 Agenda for Sustainable Development needs bold and innovative approaches to financing the projects and programs that will turn the present goals to future reality. Municipal water systems are currently under-resourced, undervalued, and under-priced (Rogers et al., 2002). Projects financed through external aid and philanthropy have led to less sustainable outcomes - and user paid instruments (tariffs, taxes, and concessional funding through bonds or loans) can been more viable alternatives. However, what is really needed is a departure from business-as-usual for implementing the SDGs. We actively

needs to meeting ecosystem needs as well (Pahl-Wostl et al., 2016). In the paper here, water security has been referred to as basic human water needs. seek new models of financing as well as project evaluation, noting that there are significant opportunities to mobilize public and private capital if investment risks are reduced and willingnessto-pay is adequately recognized.

There are a number of innovative practices that have been developed in recent years to fund social services. These can serve as useful examples for new financing models. Approaches such as donor funds (that receive no returns) serving as seed capital for social service providers and commercial investors providing remaining needed funds to support the service and receiving competitive returns are among a number of creative financial solutions that are being implemented by non-profit organizations (Bugg-Levine et al., 2012). Innovation for financing and implementation of the SDGs will be about finding the unique systemic arrangement of incentives that are attractive for all relevant stakeholders.

In addition to new models, we need to address the accounting and evaluation of projects to shape the course of development on sustainable paths (UN, 2015). The financial models need to account for the fact that environmental goals, laid out in the SDGs, matter. The current system of accounting, with long time horizons that push costs of environmental impacts out in the future, distorts the evaluation of projects. The equation for financing needs to change in fundamental ways. The real value and costs of ecosystem services should thus be accounted for up front rather than ignored with assumptions of paying for damages later. As we include costs of environmental impacts and value of ecosystem services, the affordability aspects remain important. We will have to be astute in ensuring that a "cannibalistic economy" is not created, i.e., the net impacts of development should not add up to costs that cities and municipalities are unable to bear.

New financing models and accounting approaches will be an important but not the only advancement that will be needed. New technologies and business models will be key for overcoming traditional barriers. For instance, large capital investment for WASH infrastructure has remained a continuing challenge toward large-scale deployment in developing countries. A number of new ventures are now offering distributed low-cost solutions, with integrated waste value chain business models, that convert the collected waste into organic fertilizer and renewable energy (Auerbach, 2016).

For new infrastructure and development solutions, using traditional financing mechanisms, risk reduction is a key element for stimulating investment. With competitive returns, or at least reduced risks than what has traditionally been the case for water sector projects, we may find that there is a willingness to invest, and previously untapped resources become accessible. Risk reduction goes hand in hand with good governance-the drain of corruption has been a major barrier that has stalled investment in the water sector. Public or private investment, however, does find its way where there is substantive evidence of success. Research shows in some cases that users are prepared to pay more for water services if they benefit from the improved service (Bhaduri and Kloos, 2013). There is a willingness to pay if the benefits can be perceived and received by the users of water. New models which are economical and deliver service 
sustainability will increase confidence and initiate a "virtuous cycle" of further investments.

To meet human water needs, we have relied mainly on conventional human-engineered structures, but sole reliance on gray infrastructure may alter important biophysical process needed to sustain a livelihood, ecosystem and habits (Palmer et al., 2015). Complementing the gray infrastructure with green infrastructure are critical to support or preserves the functionality of gray infrastructure (an increase of lifespan of dams) and meeting water needs of current and future generation.

There are multiple challenges in financing green infrastructure also. Many countries do not consider investment in green infrastructure as part of capital expenditure (Bunn et al., 2016). The question remains how the cost of maintaining the green infrastructure can be recovered. Payment for watershed services can potentially provide the financial mechanism to that restore ecosystem service. There are around 350 active programs now on watershed development, with a total investment of around $\$ 10$ billion and covering activities on 365 million hectares (Bennett and Carroll, 2014). It is also expected that such schemes may attract private sector funding to support comprehensive environmental management. With a high level of uncertainty, often such payments are determined below market rate and lead to under-investment. An individual may build green infrastructure on the basis of saving the cost of gray infrastructure. However, such individual private investments fail to take care of the downward stream externalities. A public water fund like the Latin American Water Funds Partnership (LAWFP) ${ }^{3}$, can be used to tackle such problem and connect downstream beneficiaries to upstream land stewards, particularly in covering capital expenditure and insurance, operating expenses. This may catalyse further investment on green infrastructure.

\section{CAPACITY DEVELOPMENT AND MONITORING OF THE SDGS}

With the adoption of the SDGs, the world obliged itself to abandon the clearly unsustainable business-as-usual trajectory and to engage in finding the sustainable path toward the achievement of its societal and environmental goals. The set of 17 goals and 169 targets are conceived as benchmarks to be achieved by 2030 (some of them by 2020 or preferably earlier). In many cases, surrogate indicators will have to be used to measure progress (or the lack of it). Thus, implementation of the SDGs implies continuous monitoring and periodic evaluation to check whether the direction and pace of development are right. It implies collection, archiving, and processing of massive amount of data to be evaluated at different scales. Monitoring and evaluation have their capacity needs both regarding professional and financial resources. Substantial capacity deficits, especially in developing countries, must be addressed. Professional capacity,

\footnotetext{
${ }^{3}$ The Latin American Water Funds Partnership is the one of the first initiatives engaging the private and public sectors and civil society in a watershed conservation strategy. http://www.nature.org/ourinitiatives/regions/latinamerica/ latin-american-water-funds-partnership.xml
}

educational, and media capacity are needed since multistakeholder implementation needs informed citizens, public and private engagement and a mentality change. It is clear that, as SDG implementation commences, neither monitoring capability nor assessment capacity is at an ideal level. Thus, implementing the SDGs also requires simultaneously developing the very basis of its targeted success. The "ladder approach" epitomizing the process of gradual improvement of monitoring can also be applied to many other facets of the SDG implementation process (UN-Water, 2015).

\section{LEARNING FROM PAST LESSONS ON GOVERNANCE, TECHNICAL, TRAINING, AND SOCIAL INCENTIVES}

Building capacity in countries is important for monitoring SDGs. The increased visibility of global data platforms (like UNEP Livehttp://uneplive.unep.org/) can motivate countries to contribute data-since most senior government officials do not wish to see their countries as the "white spot" (blank) on global maps. The "tragedy of averages" however needs to be carefully avoided, since most countries have diversity in natural geography. Averaged data often presents a severely distorted characterization. The concepts such as monitoring ladders or monitoring tiers (with various levels of complexity) can be a useful and feasible trajectory for poorer countries. The enhanced capacity building could help decision makers to identify the long-term superior solutions in systemic approaches.

\section{MULTILATERAL EFFORTS FROM ALL SOCIETAL LEVELS}

All levels of society-government, academia, NGOs, and others-should be involved in SDGs monitoring. An important question is how can this be made to work in practice, and what are the challenges regarding capacity in these societal levels to contribute meaningfully. One approach is to recognize that each societal level should do what it can do best. For instance, the role of the public should be to push policy makers and government to provide services at affordable rates and sustainable practices (such as good quality drinking water, clean environment, etc.); academics need to engage in data collection and sharing, knowledge creation, and mediation of societal aspirations with sustainable development goals; administrators need to devise effective mechanisms to implement policies and meet national development aspirations and politicians need to formulate policies for societal benefits and institute rewards and penalties to enforce them.

The role of modern digital technologies, ubiquitous devices ranging from smartphones to hand-held computers can bring a sea change to data acquisition and monitoring realms. Citizen science holds a lot of promise in certain areas. However, it has its limits and will not work where data quality, calibration, and standardization are of concern. Nonetheless, it has an important role to play in raising awareness and in contributing toward efforts for monitoring as well as implementation. 


\section{CONCLUDING DISCUSSION}

The decision to incorporate a dedicated water goal (SDG6) among the 17 SDGs is a clear recognition that water is not only part of many other SDGs but in many aspects their precondition. Within this goal are fundamental targets for drinking water provision and sanitation but also for environmental sustainability. The water goal is expected to address the global water crisis as it unfolds, as evidenced by increased water scarcity, inadequate sanitation, widespread pollution, accelerated declines in freshwater biodiversity and the loss of vital ecosystem goods and services (GWSP, 2015). The paper addresses some of the challenges related to implementation and monitoring the targets of the SDGs from a water perspective, based on the key findings of a conference organized in 2015 with the focus on three essential aspects of SDGs- indicators, interlinkages, and implementation.

The paper suggests that indicators should be simple and SMART and able to inform policy makers on progress made toward sustainability and at the same time capture the complexity needed to assess the sustainability of its use. The expected set of official indicators for use in the intergovernmental progress reporting will not be able to adequately capture the progress of the SDGs and the cross-cutting role of water for their achievement. Hence, the scientific challenge to develop actionable and scientifically sound (secondary) indicators still exists. At the global level, science, for instance, can help in developing risk metrics that are required to assess whether humans are in a safe and sustainable operating space of the global water system and still can meet their essential needs. Further, water risk assessment can be conducted at the local and regional

\section{REFERENCES}

Alcamo, J. (2011). "Six assertions about the global water quality challenge," in Presented at the Congress: Futures of European Waters (Budapest). Available online at: http://www.unep.org/science/chief-scientist/Portals/76/ docs/abstract-alcamo-budapest-water-quality-25-03-11.pdf (Accessed March 24-25, 2011).

Auerbach, D. (2016). "Sustainable sanitation provision in urban slums - the energy case study," in Broken Pumps and Promises: Incentivizing Impacts in Environmental Health, ed A. T. Evan (Springer International Publishing), 211-216.

Bates, B. C., Kundzewicz, Z. W., Wu, S., and Palutikof, J. P. (eds.). (2008). "Climate change and water," in Technical Paper of the Intergovernmental Panel on Climate Change (Geneva: IPCC Secretariat), 210.

Bennett, G., and Carroll, N. (2014). Gaining Depth: State of Watershed Investment 2014. Available online at: www.ecosystemmarketplace.com/reports/sowi2014

Bhaduri, A., and Kloos, J. (2013). Getting the water prices right using an incentivebased approach: an application of a choice experiment in khorezm, uzbekistan. Eur. J. Dev. Res. 25, 680-694. doi: 10.1057/ejdr.2013.30

Biswas, A. K. (2004). Integrated water resources management: a reassessment: a water forum contribution. Water Int. 29, 248-256. doi: $10.1080 / 02508060408691775$

Bruns, A., and Frick, F. (2014). "The notion of the global water crisis and urban water realities in Accra - Perspectives from socio-hydrology," in The Global Water System in the Anthropocene, eds J. J. Bogardi, A. Bhaduri, J. Leentvaar, and S. Marx (Challenges for Science and Governance; Springer International Publishing Switzerland), 415-426.

Bugg-Levine, A., Kogut, B., and Kulatilaka, N. (2012). A new approach to funding social enterprises. Harvard Business Review, January-February Issue. level to guide social, private, and public decisions on investment and also in developing appropriate institutions and coordinating implementation plans. There is a need for the development of scientifically sound assessment and regulatory guidelines that can help to address the gaps in process understanding focusing on the interaction between stressors and their impacts on the ecosystem health of freshwater bodies. It is not perceivable that conclusive answers will be found to all of them before the implementation of SDGs starts and inherent monitoring and indicator related decisions have to be made. This implies that the scientific community must remain involved in the years to come and assist the implementation process. In many aspects it will be a "learning by doing" adaptive process.

\section{AUTHOR CONTRIBUTIONS}

$\mathrm{AB}, \mathrm{JB}, \mathrm{AS}, \mathrm{HV}$ have written the manuscript mainly. CV, CP, SB, PS, RL, HK, FR, ABR, VO have contributed ideas, concepts. SF has contributed in the groundwater section part. FR has helped in the revision of the document.

\section{ACKNOWLEDGMENTS}

We are grateful to the German Federal Ministry of Education and Research (BMBF) for their financial support provided to organize this conference. We are also thankful to several keynote speakers, panelists, moderators, rapporteurs, and participants for their inspiring ideas, guidance and stimulating debates during the plenary and parallel sessions of the conference. We also thank two reviewers and the editor for their comments and suggestions to improve the paper.

Bunn, S. E. (2016). Grand challenge for the future of freshwater ecosystems. Front. Environ. Sci. 4:21. doi: 10.3389/fenvs.2016.00021

Bunn, S., Olley, J., Smart, J., and O'Brien, L. (2016). Of Droughts and Flooding Rains. Available online at: https://medium.com/the-machinery-ofgovernment/one-year-in-one-year-on-806c9e8f9040

BWS (2013). Budapest Water Summit Statement: A Sustainable World is a Water-Secure World. Budapest. Available online at: http://www. Budapestwatersummit.hu/data/images/Budapest_Water_Summit_Statement _Final__11_October_2013.pdf

Clarke, R., Robert, L., and Dilys, R. W. (2002). Global Environment Outlook 3: Past, Present and Future Perspectives. Earthscan.

Conway, D., van Garderen, E. A., Deryng, D., Dorling, S., Krueger, T., Landman, W., et al. (2015). Climate and Southern Africa's water-energy-food nexus. Nat. Clim. Change 5, 837-846. doi: 10.1038/nclimate2735

Cronin, A. A., Breslin, N., Gibson, J., and Pedley, S. (2006). Monitoring source and domestic water quality in parallel with sanitary risk identification in Northern Mozambique to prioritise protection 24 interventions. J. Water Health 4, 333-346. doi: 10.2166/wh.2006.029

Foster, S., Chilton, J., Nijsten, G.-J., and Richts, A. (2013). Groundwater - a global focus on the 'local resource'. Curr. Opin. Environ. Sustain. 5, 685-695. doi: 10.1016/j.cosust.2013.10.010

Foster, S., and van Steenbergen, F. (2011). Conjunctive use of groundwater and surface water - a 'lost opportunity' for water management in the developing world? Hydrogeol. J. 19, 959-962. doi: 10.1007/s10040-0110734-1

Green, P. A., Vörösmarty, C. J., Harrison, I., Farrell, T., Sáenz, L., and Fekete, B. M. (2015). Freshwater ecosystem services are supporting humans: pivoting from water crisis to water solutions. Glob. Environ. Change 34, 108-118. doi: 10.1016/j.gloenvcha.2015.06.007 
Grigg, N. S. (2008). Integrated water resources management: balancing views and improving practice. Water Int. 33, 279-292. doi: 10.1080/02508060802272820

Griggs, D., Stafford-Smith, M., Gaffney, O., Rockstrom, J., Öhman, M. C., Shyamsundar, P., et al. (2013). Sustainable development goals for people and planet. Nature 495, 305-307. doi: 10.1038/495305a

GWSP (2015). Towards a Sustainable Water Future- Sustainable Development Goals: A Water Perspective. Available online at: http://sdg2015.gwsp.org/ fileadmin/images/SDG_CONF/Towards_a_Sustainable_Water_Future.pdf

Haddeland, I., Heinke, J., Biemans, H., Eisner, S., Flörke, M., Hanasaki, N., et al. (2014). Global water resources affected by human interventions and climate change. Proc. Natl. Acad. Sci. U.S.A. 111, 3251-3256. doi: $10.1073 /$ pnas. 1222475110

Harlin, J., and Kjellén, M. (2015). Water and Development: From MDGs towards SDGs. Content, 8. Available online at: http://programme.worldwaterweek.org/ sites/default/files/2015_www_report_web.pdf\#page $=8$

Hák, T., Janoušková, S., and Moldan, B. (2016). Sustainable development goals: a need for relevant indicators. Ecol. Indic. 60, 565-573. doi: 10.1016/j.ecolind.2015.08.003

Hoff, H. (2011). "Understanding the Nexus," in Background Paper for the Bonn2011 Nexus (Bonn).

Hsu, A., J., Emerson, M., Levy, A., de Sherbinin, L., Johnson, O., Malik, J., et al. (2014). The 2014 Environmental Performance Index. New Haven, CT: Yale Center for Environmental Law and Policy. Available online at: http://www.epi. yale.edu

Hsu, K., Sorooshian, S., Gao, X., Braitewaite, D., and AghaKouchak, A. (2012). Monitoring Global Precipitation Using Satellites, SPIE Newsroom in Remote Sensing. doi: 10.1117/2.1201210.004475. Available online at: http://spie.org/ newsroom/4475-monitoring-global-precipitation-using-satellites

ICSU, ISSC (2015). Review of the Sustainable Development Goals: The Science Perspective. Paris: International Council for Science (ICSU).

ICSU (2016). International Council for Science. A Draft Framework for Understanding SDG Interactions. Available online at: http://bit.ly/sdginteractions

Jiménez Cisneros, B. E., Oki, T., Arnell, N. W., Benito, G., Cogley, J. G., Döll, P., et al. (2014). "Freshwater resources," in Climate Change 2014: Impacts, Adaptation, and Vulnerability. Part A: Global and Sectoral Aspects. The contribution of Working Group II to the Fifth Assessment Report of the Intergovernmental Panel on Climate Change, eds C. B. Field, V. R. Barros, D. J. Dokken, K. J. Mach, M. D. Mastrandrea, T. E. Bilir, M. Chatterjee, K. L. Ebi, Y. O. Estrada, R. C. Genova, B. Girma, E. S. Kissel, A. N. Levy, S. MacCracken, P. R. Mastrandrea, and L. L.White (Cambridge; New York, NY: Cambridge University Press), 229-269.

Krchnak, K. M., Smith, D. M., and Deutz, A. (2011). Putting Nature in the Nexus: Investing in Natural Infrastructure to Advance Water-Energy-Food Security. IUCN. Available online at: https://cmsdata.iucn.org/downloads/nexus_report. pdf

Lawford, R., Strauch, A., Toll, D., Fekete, B., and Cripe, D. (2013). Earth observations for global water security. Curr. Opin. Environ. Sustain. 5, 633-664. doi: 10.1016/j.cosust.2013.11.009

Leck, H., Conway, D., Bradshaw, M., and Rees, J. (2015). Tracing the waterenergy-food Nexus: description, theory and practice. Geogr. Compass 9, 445-460. doi: 10.1111/gec3.12222

Lu, Y., Nakicenovic, N., Visbeck, M., and Stevance, A. S. (2015). Policy: five priorities for the UN sustainable development goals-comment. Nature 520, 432-433. doi: 10.1038/520432a

Malik, O. A., Angel, H., Laura, A. J., and Alex de, S. (2015). A global indicator of wastewater treatment to inform the Sustainable Development Goals (SDGs). Environ. Sci. Policy 48, 172-185. doi: 10.1016/j.envsci.2015. 01.005

Muller, M. (2012). "Asymmetry and accountability deficits in water governance as inhibitors of effective water resource management," in E-Book Riber Basins and Change, eds J. J. Bogardi, J. Leentvaar, and H.-P. Nachtnebel. Available online at: http://www.gwsp.org/fileadmin/documents_news/GWSP_12_01_ELernbuch_Complete_RZ5.pdf

Muller, M., Asit, B., Martin-Hurtado, R., and Tortajada, C. (2015). Built infrastructure is essential. Science 349, 585-586. doi: 10.1126/science.aac7606

Nilsson, M., Griggs, D. and Visbeck, M. (2016). Map the interactions between Sustainable Development Goals. Nature 534, 320-322. doi: 10.1038/534320a
Onda, K., LoBuglio, J., and Bartram, J. (2012). Global access to safe water: accounting for water quality and the resulting impact on MDG progress. Int. J. Res. Public Pealth 9, 880-894. doi: 10.3390/ijerph9030880

Orme, M., Cuthbert, Z., Sindico, F., Gibson, J., and Bostic, R. (2015). Good transboundary water governance in the 2015 sustainable development goals: a legal perspective. Water Int. 40, 969-983. doi: 10.1080/02508060.2015.1099083

Pahl-Wostl, C. (2015). “The challenge of water governance," in Water Governance in the Face of Global Change (Springer International Publishing Switzerland), $1-10$.

Pahl-Wostl, C., Gupta, J., and Bhaduri, A. (2016). "Water security: a popular but contested concept," in Handbook on Water Security, eds C. Pahl-Wostl, A. Bhaduri, J. Gupta, and E. Elgar (Cheltenham, UK: Edward Elgar Publishing Ltd.).

Pahl-Wostl, C., Vörösmarty, C., Bhaduri, A., Bogardi, J., Rockström, J., and Alcamo, J. (2013). Towards a sustainable water future: shaping the next decade of global water research. Curr. Opin. Environ. Sustain. 5, 708-714. doi: 10.1016/j.cosust.2013.10.012

Palmer, M. A., Liu, J., John, H., M., Musonda, M., and D'Odorico, P. (2015). Manage water in a green way. Science 349, 584-585. doi: 10.1126/science.aac7778

Rasul, G. (2014). Food, water, and energy security in South Asia: a nexus perspective from the Hindu Kush Himalayan region. Environ. Sci. Policy 39, 35-48. doi: 10.1016/j.envsci.2014.01.010

Ringler, C., Wileenbockel, D., Perez, N., Rosegrant, M., Zhu, T., and Matthews, N. (2016). Global linkages among energy, food and water: an economic assessment. J. Environ. Stud. Sci. 6, 161-171. doi: 10.1007/s13412-016-0386-5

Rockström, J., Steffen, W., Noone, K., Persson, Å., Chapin, F. S. III, Lambin, E. F., et al. (2009). A safe operating space for humanity. Nature 461, 472-475. doi: $10.1038 / 461472 a$

Rogers, P., de Silva, R., and Bhatia, R. (2002). Water is an economic good: how to use prices to promote equity, efficiency, and sustainability. Water Policy 4, 1-17. doi: 10.1016/S1366-7017(02)00004-1

Schuster-Wallace, C. J., Sandford, R., Dickin, S. K., Vijay, M. M., Laycock, K., and Adeel, A. (2015). Water in the World We Want: Catalysing National Water-Related Sustainable Development. Hamilton, ON: UNU-INWEH.

Scott, C. A., Kurian, M., and Wescoat, J. L. (2015). "Chapter 2: The waterenergy-food nexus: enhancing adaptive capacity to complex global challenges," in Governing the Nexus, eds M. Kurian and R. Ardakanian (Cham: Springer International Publishing), 15-38.

Siddiqi, A., and Anadon, L. (2011). The water-energy nexus in the Middle East and North Africa. Energy Policy 39, 4529-4540. doi: 10.1016/j.enpol.2011. 04.023

Siddiqi, A., Kajenthira, A., and Anadón, L. D. (2013). Bridging decision networks for integrated water and energy planning. Energy Strategy Rev. 2, 46-58. doi: 10.1016/j.esr.2013.02.003

UN (2015). Addis Ababa Action Agenda of the Third International Conference on Financing for Development (Addis Ababa Action Agenda). Available online at: http://www.un.org/esa/ffd/wp-content/uploads/2015/08/AAAA_Outcome.pdf

UNDP (2006). Beyond Scarcity: Power, Poverty and the Global Water Crisis. Human Development Report, United Nations Development Programme (UNDP); Palgrave Macmillan.

UNEP (2007). Global Environmental Outlook (GEO 4) Environment for Development. Available online at: http://www.unep.org/geo/GEO4/report/ GEO-4_Report_Full_en.pdf

UNESCO-WWAP (2012). The United Nations World Water Development Report 4: Managing Water under Uncertainty and Risk (Vol. 1). Available online at: http://unesdoc.unesco.org/images/0021/002156/215644e.pdf

UNESCO-WWAP (2015). The United Nations World Water Development Report: Water for a Sustainable Development. Available online at: http://unesdoc. unesco.org/images/0023/002318/231823E.pdf

UNICEF and WHO (2015). Progress on Sanitation and Drinking Water - 2015 Update and MDG Assessment (Geneva).

UN-Water (2011). Water and Cities: Facts and Figures. UN-Water Decade Programme on Advocacy and Communication (UNW-DPAC).

UN-Water (2015). Consolidated Technical Input from UN Agencies on Water and Sanitation Related Indicators. Available online at: https://sustainabledevelopment.un.org/content/documents/2076Consolidated $\% 20$ Technical\%20inputs.pdf 
UN-Water (2016). Metadata on Suggested Indicators for Global Monitoring of the Sustainable Development Goal 6 on Water and Sanitation. Available online at: http://www.unwater.org/fileadmin/user_upload/unwater_new/docs/ Goal\%206_Metadata\%20Compilation\%20for\%20Suggested\%20Indicators_ UN-Water_v2016-04-01_2.pdf

Vörösmarty, C. J., Hoekstra, A. Y., Bunn, S. E., Conway, D., and Gupta, J. (2015a). Freshwater goes global. Science 349, 478-479. doi: 10.1126/science.aac6009

Vörösmarty, C. J., McIntyre, P. B., Gessner, M. O., Dudgeon, D., Prusevich, A., Green, P., et al. (2010). Global threats to human water security and river biodiversity. Nature 467, 555-561. doi: 10.1038/nature09440

Vörösmarty, C. J., Meybeck, M., and Pastore, C. L. (2015b). Impair-thenrepair: a brief history \& global-scale hypothesis regarding human-water interactions in the anthropocene. Doedalus 144, 94-109. doi: 10.1162/DAED_a_ 00345

Vörösmarty, C., Lettenmaier, D., Leveque, C., Meybeck, M., Pahl-Wostl, C., Alcamo, J., et al. (2004). Humans transforming the global water system. Eos Trans. Am. Geophys. Union 85, 509-514. doi: 10.1029/2004EO480001

Waage, J., Yap, C., Bell, S., Levy, C., Mace, G., Pegram, T., et al. (2015). Governing the UN Sustainable Development Goals: interactions, infrastructures, and institutions. Lancet Glob. Health 3, e251-e252. doi: $10.1016 /$ s2214-109x(15)70112-9
Wheater, H. S., and Gober, P. (2015). Water security and the science agenda.Water Res. Res. 51, 5406-5424. doi: 10.1002/2015WR016892

Yang, H., Stephan, P., and Anik, B. (2013). Accounting for a scarce resource: virtual water and water footprint in the global water system.Curr. Opin. Environ. Sustain. 5, 599-606. doi: 10.1016/j.cosust.2013.10.003

Zarfl, C., Lumsdon, A. E., Berlekamp, J., Tydecks, L., and Tockner, K. (2015). A global boom in hydropower dam construction. Aquat. Sci. 77, 161-170. doi: $10.1007 /$ s00027-014-0377-0

Conflict of Interest Statement: The authors declare that the research was conducted in the absence of any commercial or financial relationships that could be construed as a potential conflict of interest.

Copyright () 2016 Bhaduri, Bogardi, Siddiqi, Voigt, Vörösmarty, Pahl-Wostl, Bunn, Shrivastava, Lawford, Foster, Kremer, Renaud, Bruns and Osuna. This is an openaccess article distributed under the terms of the Creative Commons Attribution License (CC BY). The use, distribution or reproduction in other forums is permitted, provided the original author(s) or licensor are credited and that the original publication in this journal is cited, in accordance with accepted academic practice. No use, distribution or reproduction is permitted which does not comply with these terms. 